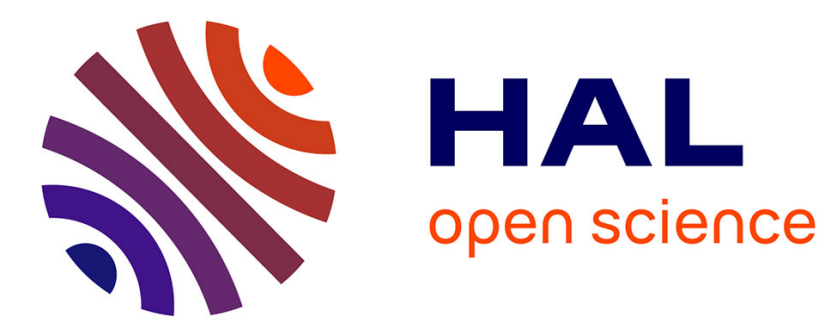

\title{
Ricardian equivalence and the intertemporal Keynesian multiplier
}

Jean-Pascal Bénassy

\section{To cite this version:}

Jean-Pascal Bénassy. Ricardian equivalence and the intertemporal Keynesian multiplier. 2006. halshs-00590509

\section{HAL Id: halshs-00590509 \\ https://shs.hal.science/halshs-00590509}

Preprint submitted on 3 May 2011

HAL is a multi-disciplinary open access archive for the deposit and dissemination of scientific research documents, whether they are published or not. The documents may come from teaching and research institutions in France or abroad, or from public or private research centers.
L'archive ouverte pluridisciplinaire HAL, est destinée au dépôt et à la diffusion de documents scientifiques de niveau recherche, publiés ou non, émanant des établissements d'enseignement et de recherche français ou étrangers, des laboratoires publics ou privés. 


\section{Paris-Jourdan ScIences EconomiQues \\ 48, BD JOURDAN - E.N.S. - 75014 PARIS \\ TEL. : 33(0) 143136300 - FAX : 33 (0) 143136310 \\ www.pse.ens.fr}

WORKING PAPER Nº 2006 - 15

Ricardian equivalence and the intertemporal

Keynesian multiplier

Jean-Pascal Bénassy

JEL Codes : E62, E63, E12

Keywords : multiplier, Ricardian equivalence, non-Ricardian economies, price rigidities, Keynesian multiplier. 


\title{
Ricardian Equivalence and the Intertemporal Keynesian Multiplier
}

\author{
Jean-Pascal Bénassy*† \\ December 2005 \\ Revised February 2006
}

\begin{abstract}
We show that Keynesian multiplier effects can be obtained in dynamic optimizing models if one combines both price rigidities and a "non Ricardian" framework where, due for example to the birth of new agents, Ricardian equivalence does not hold.
\end{abstract}

JEL Codes: E62, E63, E12

Keywords: Multiplier, Ricardian equivalence, Non Ricardian economies, Price rigidities, Keynesian multiplier.

*Address: CEPREMAP-ENS, 48 Boulevard Jourdan, Bâtiment E, 75014, Paris, France. Telephone: 33-1-43136338. Fax: 33-1-43136232. E-mail: benassy@pse.ens.fr

${ }^{\dagger} \mathrm{I}$ wish to thank Fabrice Collard and Harris Dellas, but retain responsibility for all remaining deficiencies. 


\section{Introduction}

One of the most intriguing features of traditional Keynesian theory (Keynes, 1936, Hicks, 1937) is the so called "multiplier effect" by which an increase in governement spending can create an increase in consumption, whereas in Walrasian models it leads to a decrease, via the usual "crowding out" effect. This multiplier effect is customarily attributed to price or wage rigidities.

Now in the recent evolution of macroeconomic modelling most macroeconomic issues are reexamined within the rigorous framework of dynamic intertemporal maximizing models à la Ramsey (1928). The typical model depicts consumers as one single dynasty of infinitely lived agents. This model has notably the property of "Ricardian equivalence" (Barro, 1974), according to which, in a nutshell, the distribution of taxes across time is irrelevant as long as the government balances its budget intertemporally. The model has been extended to a monetary framework (Sidrauski, 1969, Brock, 1975), where Ricardian equivalence also holds.

In line with this recent evolution, a natural question to ask is whether a multiplier effect will arise in these dynamic models. The result has been actually disappointing: crowding out occurs in the usual DSGE model (see for example Fatas and Mihov, 2001), and even in models with price rigidities under standard parameterizations (see for example Collard and Dellas, 2005).

What we want to show in this paper is that, in order to obtain a strong enough multiplier effect, another ingredient, in addition to price rigidities, has to be introduced in dynamic models. Namely one should not only have price rigidities, but also model the economy as "non Ricardian". By non Ricardian economies we mean, as in Barro (1974), economies like overlapping generations (OLG) economies à la Samuelson (1958), where Ricardian equivalence does not hold. The non Ricardian economy we shall work with is due to Weil $(1987,1991)$. It is a monetary economy where, as in the Ricardian model, agents have an infinite life but, as in the OLG model, new agents arrive over time.

We shall call $n$ the rate of growth of the population. In a nutshell the results are: If $n>0$, there is a multiplier ${ }^{1}$, and government spending leads to an increase in private consumption. This multiplier is larger, the higher $n$ is, i.e. the more "non Ricardian" the economy is.

\footnotetext{
${ }^{1} \mathrm{By}$ this we mean more precisely that the income multiplier is greater than one, so that there is no crowding out.
} 


\section{The model}

We shall thus use the model of Weil $(1987,1991)$, which has the great advantage of having the Ricardian model as a particular case. Each household lives forever, but new "generations" are born every period. Denote as $N_{t}$ the number of households alive at time $t$. We will work below with a constant rate of growth of the population $n \geq 0$, so that $N_{t}=(1+n)^{t} N_{0}$. The Ricardian model corresponds to the special limit case $n=0$.

\subsection{Households}

Consider a household born in period $j$. We denote by $c_{j t}, y_{j t}$ and $m_{j t}$ his consumption, endowment and money holdings at time $t \geq j$. This household maximizes the following utility function:

$$
U_{j t}=\sum_{s=t}^{\infty} \beta^{s-t} \log c_{j s}
$$

and is submitted in period $t$ to a "cash in advance" constraint:

$$
P_{t} c_{j t} \leq m_{j t}
$$

Household $j$ begins period $t$ with a financial wealth $\omega_{j t}$. First the bond market opens, and the household lends an amount $b_{j t}$ at the nominal interest rate $i_{t}$. The rest is kept under the form of money $m_{j t}$, so that:

$$
\omega_{j t}=m_{j t}+b_{j t}
$$

Then the goods market opens, and the household sells his endowment $y_{j t}$, pays taxes $\tau_{j t}$ in real terms and consumes $c_{j t}$, subject to the cash constraint (2). Consequently, the budget constraint for household $j$ is:

$$
\omega_{j t+1}=\left(1+i_{t}\right) \omega_{j t}-i_{t} m_{j t}+P_{t} y_{j t}-P_{t} \tau_{j t}-P_{t} c_{j t}
$$

\subsection{Aggregation, endowments and taxes}

Aggregate quantities are obtained by summing the various individual variables. There are $N_{j}-N_{j-1}$ agents in generation $j$, so for example aggregate taxes $\mathcal{T}_{t}$ are given by:

$$
\mathcal{T}_{t}=\sum_{j \leq t}\left(N_{j}-N_{j-1}\right) \tau_{j t}
$$


The other aggregate quantities, $Y_{t}, C_{t}, \Omega_{t}, M_{t}$ and $B_{t}$, are deduced through similar formulas from the individual variables, $y_{j t}, c_{j t}, \omega_{j t}, m_{j t}$ and $b_{j t}$.

We now have to describe the distribution of endowments and taxes among households. We assume that all households have the same income and taxes:

$$
y_{j t}=y_{t}=\frac{Y_{t}}{N_{t}} \quad \tau_{j t}=\tau_{t}=\frac{\mathcal{T}_{t}}{N_{t}}
$$

\section{The dynamic equations}

\subsection{Taxes and government budget constraint}

The dynamics of government liabilities $\Omega_{t}$ is:

$$
\Omega_{t+1}=\left(1+i_{t}\right) \Omega_{t}-i_{t} M_{t}+P_{t} G_{t}-P_{t} \mathcal{T}_{t}
$$

Government budget balance corresponds to $\Omega_{t+1}=\Omega_{t}$, i.e. since $\Omega_{t}=$ $M_{t}+B_{t}$ :

$$
P_{t} G_{t}=P_{t} \mathcal{T}_{t}-i_{t} B_{t}
$$

We would like to have a tax index $T_{t}$ such that budget balance is achieved under the traditional condition:

$$
G_{t}=T_{t}
$$

This will be the case if we define $T_{t}$ through:

$$
P_{t} T_{t}=P_{t} \mathcal{T}_{t}-i_{t} B_{t}
$$

Budget balance now corresponds to (9), and the government budget constraint (7) is rewritten as:

$$
\Omega_{t+1}=\Omega_{t}+P_{t} G_{t}-P_{t} T_{t}
$$

\subsection{Consumption dynamics}

The dynamics of consumption is given by (see the appendix):

$$
P_{t+1} C_{t+1}=\beta(1+n)\left(1+i_{t}\right) P_{t} C_{t}-(1-\beta) n \Omega_{t+1}
$$

The dynamic system consists of equations (11) and (12). 


\section{The multiplier}

We shall assume that nominal prices are fully rigid, now and in the future. Besides simplifying the algebra this assumption, which is clearly the most favourable situation for a multiplier effect to arise, will allow to make crystalclear that a non Ricardian environment plays a central role in addition to price rigidities. We also assume that the nominal interest rate is pegged $\left(i_{t}=i\right)$. Now equation (12) is rewritten:

$$
\begin{gathered}
P_{t} C_{t}=\gamma P_{t+1} C_{t+1}+\gamma(1-\beta) n \Omega_{t+1} \\
=\gamma P_{t+1} C_{t+1}+\gamma(1-\beta) n\left(\Omega_{t}+P_{t} G_{t}-P_{t} T_{t}\right)
\end{gathered}
$$

with:

$$
\gamma=\frac{1}{\beta(1+n)(1+i)}
$$

We shall assume $\gamma<1^{2}$. Integrating forward equation (13) we obtain:

$$
P_{t} C_{t}=\gamma(1-\beta) n \sum_{j=0}^{\infty} \gamma^{j}\left(\Omega_{t+j}+P_{t+j} G_{t+j}-P_{t+j} T_{t+j}\right)
$$

Now from (11):

$$
\Omega_{t+j}=\Omega_{t}+\sum_{k=0}^{j-1} P_{t+k}\left(G_{t+k}-T_{t+k}\right)
$$

so that:

$$
\begin{gathered}
\sum_{j=0}^{\infty} \gamma^{j} \Omega_{t+j}=\sum_{j=0}^{\infty} \gamma^{j}\left[\Omega_{t}+\sum_{i=0}^{j-1} P_{t+k}\left(G_{t+k}-T_{t+k}\right)\right] \\
=\frac{\Omega_{t}}{1-\gamma}+\sum_{k=0}^{\infty} P_{t+k}\left(G_{t+k}-T_{t+k}\right) \sum_{j=k+1}^{\infty} \gamma^{j} \\
=\frac{\Omega_{t}}{1-\gamma}+\sum_{k=0}^{\infty} \frac{\gamma^{k+1}}{1-\gamma} P_{t+k}\left(G_{t+k}-T_{t+k}\right)
\end{gathered}
$$

and finally, inserting (17) into (15):

\footnotetext{
${ }^{2}$ This condition also plays a role for price determinacy in models with market clearing. See Bénassy (2005) for a formal analysis and economic discussion.
} 


$$
P_{t} C_{t}=\frac{\gamma(1-\beta) n}{1-\gamma}\left[\Omega_{t}+\sum_{j=0}^{\infty} \gamma^{j} P_{t+j}\left(G_{t+j}-T_{t+j}\right)\right]
$$

So with $n>0$ consumption reacts positively to government spending, and from formula (18) the multiplier is greater, the higher $n$ is.

\section{Conclusion}

We have thus seen that in order to obtain a "multiplier", price rigidities are not the only decisive ingredient, but it is also important to have a "non Ricardian" economy, corresponding here to $n>0$. We shall now give a brief intuition for this.

Let us start with the limit case $n=0$. As we shall now see the argument is quite reminiscent of the famous "balanced budget multiplier" of Haavelmo (1945). Consider indeed an increase in government spending, say $G_{t}$, all other spending variables being held constant. Because of the government's intertemporal budget constraint, $G_{t}$ will have to be compensated by taxes, either now or in the future, and the total discounted value of these taxes must be exactly equal to $G_{t}$. As a result we have a "balanced budget" formula, as in Haavelmo.

Now if $n>0$, new generations arrive over time, and the future, but yet unborn, generations will bear some of the future taxes. So there is part of government spending that will not be paid by currently alive generations, and as a result the traditional multiplier mechanism comes into play.

\section{Appendix: derivation of equation (12)}

We shall derive in this appendix the dynamic equation (12). Consider the household's budget equation (4). We assume that $i_{t}$ is strictly positive, so households always want to satisfy the "cash in advance" equation (2) exactly. We thus have $m_{j t}=P_{t} c_{j t}$ and equation (4) is rewritten:

$$
\omega_{j t+1}=\left(1+i_{t}\right) \omega_{j t}+P_{t} y_{t}-P_{t} \tau_{t}-\left(1+i_{t}\right) P_{t} c_{j t}
$$

Define the intertemporal discount factors:

$$
R_{t}=\prod_{s=0}^{t-1} \frac{1}{1+i_{s}} \quad R_{0}=1
$$


Applying the discount factors (20) to the budget constraint (19), it becomes:

$$
R_{s+1} \omega_{j s+1}=R_{s} \omega_{j s}+R_{s+1} P_{s}\left(y_{s}-\tau_{s}\right)-R_{s} P_{s} c_{j s}
$$

If we aggregate all discounted budget constraints (21) from time $t$ to infinity, and assume that $R_{s} \omega_{j s}$ goes to zero as $s$ goes to infinity (the usual transversality condition), we obtain the intertemporal budget constraint of the household:

$$
\sum_{s=t}^{\infty} R_{s} P_{s} c_{j s}=R_{t} \omega_{j t}+\sum_{s=t}^{\infty} R_{s+1} P_{s}\left(y_{s}-\tau_{s}\right)
$$

Now maximizing utility function (1) subject to the intertemporal budget constraint (22) yields the following consumption function for a household $j$ :

$$
R_{t} P_{t} c_{j t}=(1-\beta)\left[R_{t} \omega_{j t}+\sum_{s=t}^{\infty} R_{s+1} P_{s}\left(y_{s}-\tau_{s}\right)\right]
$$

Summing this across the $N_{t}$ agents alive in period $t$, we obtain the aggregate consumption $C_{t}$ :

$$
R_{t} P_{t} C_{t}=(1-\beta)\left[R_{t} \Omega_{t}+N_{t} \sum_{s=t}^{\infty} R_{s+1} P_{s}\left(y_{s}-\tau_{s}\right)\right]
$$

In equilibrium $Y_{t}=C_{t}+G_{t}$, so the equilibrium equation is:

$$
R_{t} P_{t}\left(Y_{t}-G_{t}\right)=(1-\beta)\left[R_{t} \Omega_{t}+N_{t} \sum_{s=t}^{\infty} R_{s+1} P_{s}\left(y_{s}-\tau_{s}\right)\right]
$$

Divide both sides by $N_{t}$ and use $Y_{t}=N_{t} y_{t}, G_{t}=N_{t} g_{t}$ :

$$
R_{t} P_{t}\left(y_{t}-g_{t}\right)=(1-\beta)\left[\frac{R_{t} \Omega_{t}}{N_{t}}+\sum_{s=t}^{\infty} R_{s+1} P_{s}\left(y_{s}-\tau_{s}\right)\right]
$$

Let us rewrite this equation for $t+1$ and subtract it from (26). We obtain:

$$
\begin{gathered}
R_{t} P_{t}\left(y_{t}-g_{t}\right)-R_{t+1} P_{t+1}\left(y_{t+1}-g_{t+1}\right)= \\
(1-\beta)\left[\frac{R_{t} \Omega_{t}}{N_{t}}-\frac{R_{t+1} \Omega_{t+1}}{N_{t+1}}+R_{t+1} P_{t}\left(y_{t}-\tau_{t}\right)\right]
\end{gathered}
$$

Now multiply the government's budget equation (7) by $R_{t+1} / N_{t}$ : 


$$
\frac{R_{t} \Omega_{t}}{N_{t}}=\frac{R_{t+1} \Omega_{t+1}}{N_{t}}+\left(R_{t}-R_{t+1}\right) P_{t}\left(y_{t}-g_{t}\right)-R_{t+1} P_{t} g_{t}+R_{t+1} P_{t} \tau_{t}
$$

Insert this into equation (27):

$$
R_{t+1} P_{t+1}\left(y_{t+1}-g_{t+1}\right)=\beta R_{t} P_{t}\left(y_{t}-g_{t}\right)-(1-\beta)\left(\frac{1}{N_{t}}-\frac{1}{N_{t+1}}\right) R_{t+1} \Omega_{t+1}
$$

and multiply by $N_{t+1} / R_{t+1}$ :

$$
P_{t+1}\left(Y_{t+1}-G_{t+1}\right)=\beta \frac{N_{t+1}}{N_{t}}\left(1+i_{t}\right) P_{t}\left(Y_{t}-G_{t}\right)-(1-\beta)\left(\frac{N_{t+1}}{N_{t}}-1\right) \Omega_{t+1}
$$

Taking finally $N_{t+1} / N_{t}=1+n$, and using $C_{t}=Y_{t}-G_{t}$ we obtain:

$$
P_{t+1} C_{t+1}=\beta(1+n)\left(1+i_{t}\right) P_{t} C_{t}-(1-\beta) n \Omega_{t+1}
$$

which is equation (12).

\section{References}

[1] Barro, Robert J. (1974), "Are government bonds net wealth?", Journal of Political Economy, vol. 82, pp 1095-1117.

[2] Bénassy, Jean-Pascal (2005), "Interest rate rules, price determinacy and the value of money in a non-Ricardian world", Review of Economic Dynamics, vol. 8, pp 651-667.

[3] Brock, William A. (1975) "A simple perfect foresight monetary model", Journal of Monetary Economics, vol. 1, pp 133-150.

[4] Collard, Fabrice and Harris Dellas (2005), "Poole in the new Keynesian model", Europen Economic Review, vol. 49, pp 887-907.

[5] Fatas, Antonio and Ilian Mihov (2001), "The effects of fiscal policy on consumption and employment: theory and evidence", working paper, INSEAD.

[6] Haavelmo, Trygve (1945), "Multiplier effects of a balanced budget", Econometrica, vol. 11, pp 1-12. 
[7] Hicks, John R. (1937), "Mr. Keynes and the "classics": a suggested interpretation", Econometrica, vol. 5, pp 147-159.

[8] Keynes, John Maynard (1936), The General Theory of Employment, Interest and Money. New York: Harcourt Brace.

[9] Ramsey, Frank P. (1928), "A mathematical theory of saving", Economic Journal, vol. 38, pp 543-559.

[10] Samuelson, Paul A. (1958), "An exact consumption-loan model of interest with or without the social contrivance of money", Journal of Political Economy, vol. 66, pp 467-482.

[11] Sidrauski, Miguel (1967), "Rational choice and patterns of growth in a monetary economy", American Economic Review, vol. 57, supplement, pp 534-544.

[12] Weil, Philippe (1987), "Permanent budget deficits and inflation", Journal of Monetary Economics, vol. 20, pp 393-410.

[13] Weil, Philippe (1991), "Is money net wealth?", International Economic Review, vol. 32, 37-53. 